\title{
Individual and cumulative impacts of fire emissions and tobacco consumption on wildland firefighters' total exposure to polycyclic aromatic hydrocarbons
}

\author{
Marta Oliveira ${ }^{\mathrm{a}, \mathrm{b}}$, Klara Slezakova ${ }^{\mathrm{a}, \mathrm{b}}$, Carlos Pires Magalhães ${ }^{\mathrm{c}}$, Adília Fernandes ${ }^{\mathrm{c}}$, \\ João Paulo Teixeira ${ }^{\mathrm{d}, \mathrm{e}}$, Cristina Delerue-Matos ${ }^{\mathrm{a}}$, Maria do Carmo Pereira ${ }^{\mathrm{b}}$, \\ Simone Morais ${ }^{\mathrm{a}, *}$ \\ a REQUIMTE-LAQV, Instituto Superior de Engenharia, Instituto Politécnico do Porto, Rua Dr. António Bernardino de Almeida 431, 4200-072 Porto, Portugal \\ b LEPABE, Departamento de Engenharia Química, Faculdade de Engenharia, Universidade do Porto, Rua Dr. Roberto Frias, $4200-465$ Porto, Portugal \\ c Escola Superior de Saúde, Instituto Politécnico de Bragança, Bragança, Portugal \\ d Instituto Nacional de Saúde Pública, Departamento de Saúde Ambiental, Rua Alexandre Herculano 321, 4000-055 Porto, Portugal \\ e Universidade do Porto, Instituto de Saúde Pública, Rua das Taipas 135, 4050-600 Porto, Portugal
}

\section{H I G H L I G H T S}

- Impact of fire emissions and smoking on firefighters' exposure to PAHs was assessed.

- Smoking increased $76-412 \%$ the levels of total urinary metabolites (OH-PAHs).

- Firefighting activities raised $158-551 \%$ the total OH-PAHs concentrations.

- 2-hydroxyfluorene was the most affected metabolite by firefighting activities.

- 10 HNaph + 10HAce presented the more pronounced increase due to tobacco consumption.

\section{A R T I C L E I N F O}

\section{Article history:}

Received 27 December 2016

Received in revised form 19 March 2017

Accepted 24 March 2017

Available online 27 March 2017

\section{Keywords:}

Biomonitoring

Firemen

Occupational exposure

Tobacco smoking

Urinary monohydroxyl metabolites

(OH-PAHs)

\begin{abstract}
A B S T R A C T
There is limited information about wildland firefighters' exposure to polycyclic aromatic hydrocarbons (PAHs), being scarce studies that included the impact of tobacco consumption. Thus, this work evaluated the individual and cumulative impacts of firefighting activities and smoking on wildland firefighters' total exposure to PAHs. Six urinary PAH metabolites (1-hydroxynaphthalene (1OHNaph), 1-hydroxyacenaphthene (1OHAce), 2-hydroxyfluorene (2OHFlu), 1-hydroxyphenanthrene (10HPhen), 1-hydroxypyrene (10HPy), and 3-hydroxybenzo[a]pyrene (3OHB[a]P)) were quantified by high-performance liquid chromatography with fluorescence detection. Firefighters from three fire stations were characterized and organized in three groups: non-smoking and non-exposed to fire emissions (NSNExp), smoking non-exposed (SNExp), and smoking exposed (SExp) individuals. 1OHNaph $+10 H A c e$ were the most predominant OH-PAHs (66-91\% $\left.\sum \mathrm{OH}-\mathrm{PAHs}\right)$, followed by $2 \mathrm{OHFlu}(2.8-28 \%), 10 \mathrm{HPhen}$ (1.3-7\%), and 1OHPy (1.4-6\%). 3OHB[a]P, the carcinogenicity PAH biomarker, was not detected. Regular consumption of tobacco increased $76-412 \% \sum \mathrm{OH}-\mathrm{PAHs}$. Fire combat activities promoted significant increments of $158-551 \% \sum \mathrm{OH}-\mathrm{PAHs}$. 2OHFlu was the most affected compound by firefighting activities (111-1068\%), while 1 OHNaph +10 HAce presented the more pronounced increments due to tobacco consumption (22-339\%); 10HPhen (76-176\%) and 10HPy (20-220\%) were the least influenced ones. $\mathrm{OH}-\mathrm{PAH}$ levels of SExp firefighters were significantly higher than in other groups, suggesting that these subjects may be more vulnerable to develop and/or aggravate diseases related with PAHs exposure.
\end{abstract}

(c) 2017 Elsevier B.V. All rights reserved.

\footnotetext{
* Corresponding author.

E-mail address: sbm@isep.ipp.pt (S. Morais).
}

\section{Introduction}

Human biomonitoring allows assessment of total personal exposure, including environmental and workplace hazardous chemicals, through the analysis of chemicals and/or their metabo- 
lites in human exhaled air, blood, urine, milk, saliva, nails, hair, faeces, and adipose tissue $[1,2]$. Among the many human matrices, urine is by far the most common one [3-5]. Thus the use of human biomonitoring is a precious tool as it estimates the total internal dose regardless of the source, route, and duration of the exposure.

Occupational exposure of firefighters, i.e. firefighters directly involved in firefighting activities, was classified as a possible carcinogen to humans by the International Agency for Research on Cancer (IARC group 2B; [6]) and the US National Institute for Occupational Safety and Health (NIOSH; [7]). Wildland firefighters are frequently exposed to numerous pollutants (particulate matter, carbon monoxide, nitrogen dioxide, volatile organic compounds including polycyclic aromatic hydrocarbons (PAHs), polybrominated diphenyl ethers, polychlorinated dibenzo-p-dioxin, etc.) that are released during fires [5,8-13]. Exposure to wildfire smoke is being associated with respiratory morbidity with growing evidence supporting an association with all-cause mortality, being consistently related with cardiovascular effects, specific causes of mortality, birth outcomes, and mental health disorders [14].

Tobacco consumption is an additional risk factor for potential health effects, since prolonged exposure to tobacco smoke is, by itself, the major cause of lung cancer [15]. Tobacco smoke is a complex mixture of thousands of chemical substances including over 69 known carcinogens; therefore, tobacco smoking and its exposure are classified as known human carcinogens by most of the international agencies $[15,16]$.

In terms of the main constituents isolated from the mainstream smoke of cigarettes and air emissions released during wildland and agricultural fires, PAHs are a relevant group of compounds that cause carcinogenic effects [15]. PAHs are ubiquitous pollutants that are included in the lists of priority pollutants of the European Union [17] and US Environmental Protection Agency [18] due to their mutagenic and carcinogenic properties [19-21]. They are formed during incomplete combustion of organic matter and originate from both natural and anthropogenic sources [22,23]. Human exposure to PAHs occurs by all routes of exposure, namely inhalation, ingestion, and skin contact [8,24-28]. Once absorbed into blood stream, PAHs are biotransformed and distributed within human body, being mostly eliminated through urine as glucuronide and/or sulfate conjugates $[22,29,30]$. Thus, urinary metabolites of PAHs (OH-PAHs) reflect a more accurate estimation of the total exposure. Urinary 1-hydroxypyrene (10HPy), the major metabolite of pyrene, is the most frequently used biomarker to assess PAHs exposure [1,11,31-33]. 3-hydroxybenzo[a]pyrene (3OHB[a]P) is one of the metabolites of benzo[a]pyrene, and it is considered as the PAH biomarker of carcinogenicity [32]. 1-hydroxynaphthalene (1OHNaph) is frequently used to assess the exposure to naphthalene [34], a PAH that was selected as an important indicator of indoor air pollution by the World Health Organization (WHO) [35]. Due to the ubiquity of PAHs, their various sources and routes of exposure, the use of more than one PAHs biomarker better characterizes the total exposure of a subject.

Despite the undeniable role that firefighters play in maintaining population safety, limited information related with their occupational exposure to PAHs is available in the literature $[4,5,11,31,33,34,36-38]$, being scarce studies that included the impact of tobacco consumption [34,37]. Moreover, biomonitoring of wildland firefighter's exposure to PAHs from fire emissions has been mostly performed during training exercises $[11,34,37,38]$ and typically based exclusively on 10HPy analysis [31,33,37,38]. Exposure to PAHs has been associated with the development and/or aggravation of lung function reduction, specifically with exacerbations of asthma and chronic obstructive pulmonary disease, some cardiovascular pathologies and cancer [39-41]. Excess morbidity and mortality in firefighters have been related with those diseases and some selected site-specific cancers comparatively with general population [42-47].

Thus, the present study aims to characterize the impact of tobacco consumption and occupational exposure on wildland firefighters' total exposure to PAHs. Six urinary PAH metabolites (1OHNaph, 1-hydroxyacenaphthene (1OHAce), 2hydroxyfluorene (2OHFlu), 1-hydroxyphenanthrene (1OHPhen), $1 \mathrm{OHPy}$ and $3 \mathrm{OHB}[\mathrm{a}] \mathrm{P}$ ) were determined in three different groups of subjects: i) non-smoking non-exposed firefighters (NSNExp) who were not involved in firefighting activities within the previous week of urine sampling, ii) smoking firefighters who were not exposed to any kind of fire emissions (SNExp), and iii) smoking exposed firefighters (SExp) who actively participated in wildland fire combat activities (knockdown and/or overhaul) within the $48 \mathrm{~h}$ prior the urine collection. Comparison between the urinary levels of individual and total OH-PAHs among the three groups was conducted in order to evaluate the individual and cumulative impacts of the tobacco consumption and participation in firefighting activities on wildland firefighters' total exposure to PAHs.

\section{Materials and methods}

\subsection{Characterization of the study population}

A total of 108 healthy firefighters serving at three different fire stations, namely Vinhais (VNH), Mirandela (MDL) and Bragança (BRG) participated in this study. Fire stations were situated in Trás-os-Montes and Alto Douro Region, the Northeast area of the country that is every year strongly affected by wildfires [48]. This geographical area is characterized by very hot and dry summers, and cold winters. All firefighters of the selected fire stations were requested to fill a structured questionnaire, which was adapted from a validated form [49]. The questionnaire was used to collect firefighters' personal information on age, weight, number of years of occupational exposure as firefighters, time dedicated to firefighting activities in the last $48 \mathrm{~h}$ and the use of personal protective equipment during that period; exposure to environmental tobacco smoke, tobacco smoking habits (including the number of cigarettes smoked per day for smokers), and the most frequently consumed meals (boiled, roasted, and grilled) during the week before urine collection. Also, some clinical parameters, such as cardiac frequency, individual diastolic and systolic blood pressure (Geratherm Desktop, Geratherm Medical AG, Geschwenda, Germany), and the arterial oxygen saturation (Oxy-100 pulse oximeter, Gima, Italy) were measured in each participant at the end of the work shift. Body mass index (BMI; $\mathrm{kg} / \mathrm{m}^{2}$ ) was determined for each fireman. According to the information collected through the questionnaires, firefighters were organized into three different groups: NSNExp, SNexp and Sexp. The protocol was reviewed and approved by the Ethic Committee of University of Porto, Portugal (Project Ethics Committee No. 12/CEUP/2015) and all participants gave a written informed consent.

\subsection{Urine sampling, extraction and chromatographic analysis}

Collection campaigns were performed at the three fire stations during June to September 2015. All firefighters were asked to collect a spot urine sample at the end of a regular work shift between Tuesday and Thursday in order to avoid the impact of different personal weekend activities. Urine samples were collected in sterilized $50 \mathrm{~mL}$ polycarbonate containers and frozen at $-20^{\circ} \mathrm{C}$ until analysis.

Extraction and chromatographic analysis of urinary OH-PAHs were done according to Oliveira et al. [5] and Chetiyanukornkul et al. [50]. Calibration curves were prepared with $\mathrm{OH}-\mathrm{PAH}$ mixed standards in methanol except for 10HNaph and/or 10HAce 
that were quantified with a matrix-matched calibration curve; they presented good correlation coefficients ( 6 calibration points; $\mathrm{R}^{2} \geq 0.9979$ ). The methodology was validated by recovery experiments with values ranging from 70.0 to $117.5 \%$. Detection limits varied between $0.0008 \mu \mathrm{g} / \mathrm{L}$ urine for $20 H F l u$ to $0.195 \mu \mathrm{g} / \mathrm{L}$ urine for $10 H N a p h+10 H A c e$ with respective quantification limits ranging from 0.0028 to $0.650 \mu \mathrm{g} / \mathrm{L}$ urine. Intra and inter-precision assays were performed during six consecutive days with RSD values ranging from $1.3 \%$ (2OHFlu) to $6.4 \%$ (1OHPhen) and between $1.3 \%$ to $8.1 \%$ $(10$ HNaph + 1OHAce, and 10HPy), respectively [5]. Representative chromatograms are exhibited in Fig. 1S (Supplementary material).

Urinary creatinine levels $(\mu \mathrm{mol} / \mathrm{mol}$ ) were quantified according to the Jaff colorimetric method [51] and used to normalize the urinary concentrations of OH-PAHs.

All determinations were performed in triplicate.

\subsection{Statistical treatment}

Statistical analysis was performed using SPSS (IBM SPSS Statistics 20) and Statistica (v. 7, StatSoft Inc., USA) software. Median values of individual and $\Sigma \mathrm{OH}-\mathrm{PAH}$ were compared through the nonparametric Mann-Whitney $U$ test since normal distribution was not observed by Shapiro-Wilk's test. Statistical significance was defined as $p \leq 0.05$.

\section{Results and discussion}

\subsection{Characterization of the study population}

The overall mean ages were 34 years for NSNExp (22-48 years) and SNExp (21-60 years) firefighters, while SExp subjects had a mean age of 31 years (21-53 years); no statistical difference $(p>0.05)$ was observed between the three groups.

BMI, the most commonly used index of weight-for-height, is a tool commonly used to classify underweight $\left(<18.5 \mathrm{~kg} / \mathrm{m}^{2}\right)$, normal weight $\left(18.5-25 \mathrm{~kg} / \mathrm{m}^{2}\right)$, overweight $\left(25-30 \mathrm{~kg} / \mathrm{m}^{2}\right)$, and obesity (degree I: $30-35 \mathrm{~kg} / \mathrm{m}^{2}$; degree II: $35-40 \mathrm{~kg} / \mathrm{m}^{2}$; degree III: $\geq 40 \mathrm{~kg} / \mathrm{m}^{2}$ ) in adults [52]. The overall BMI values ranged between $19 \mathrm{~kg} / \mathrm{m}^{2}$ (SNExp of VNH and SExp of MDL) to $36 \mathrm{~kg} / \mathrm{m}^{2}$ (NSNExp of BRG) (mean $25 \mathrm{~kg} / \mathrm{m}^{2}$ ) (Table 1 ). A total of $61 \%$ of firefighters had normal BMI values; $22 \%$ of NSNExp, 3\% of SNExp, and $14 \%$ of SExp individuals presented BMI values higher than $25 \mathrm{~kg} / \mathrm{m}^{2}$, suggesting an overweight. Significant differences of BMI levels were observed between NSNExp $\left(28 \mathrm{~kg} / \mathrm{m}^{2}\right)$ and SNExp $\left(24 \mathrm{~kg} / \mathrm{m}^{2}\right.$; $p=0.05)$ groups, and among NSNExp and SExp subjects $\left(24 \mathrm{~kg} / \mathrm{m}^{2}\right.$; $p=0.013)$. NSNExp firefighters serving at MDL and BRG fire corporations had mean BMI levels indicative of overweight, with some individuals revealing values of degree I and II of obesity [52] (Table 1). Obesity is a nutritional pathology that may conduct to the development of health problems [52]. The determined BMI levels are in accordance with the national report, which indicated that $52.8 \%$ of the Portuguese adult population was overweight in 2014 [53].

Arterial hypertension is an asymptomatic disease characterized by continually elevated blood pressure, usually diastolic blood pressure $\geq 90 \mathrm{mmHg}$ and/or systolic blood pressure $\geq 140 \mathrm{mmHg}$ [54]. The values of diastolic and systolic blood pressure in firefighters ranged between 49 and 114 and $120-152 \mathrm{mmHg}$ for NSNExp, 61-97 and 108-152 mmHg for SNExp and from 60 to 98 and 113-156 mmHg for SExp subjects, respectively. A total of $83 \%$ of NSNExp and SNExp, and 61\% of SExp firefighters presented normal values of blood pressure; $17 \%$ (NSNExp and SNExp) to $39 \%$ (SExp) of the participants revealed to have levels higher than the recommended limits (Table 1 ). The cardiac frequency observed in firefighters was overall within the recommended range of $60-100$ heart beats/min [55]. The arterial oxygen saturation values were also within the normal range of $95-100 \%$ [55].

\subsection{Detection rates of $\mathrm{OH}-\mathrm{PAHS}$}

The detection of urinary OH-PAHs confirms the exposure to PAHs, regardless of the source. The collection of spot urine samples in occupational biomonitoring studies is frequently used, however the variability in the volume of urine collected and its total water content needs to be taken into consideration. To overcome these limitations, the creatinine adjustment is the most frequently used method to normalize the concentrations of urinary metabolites [56], thus it was applied in this study. Creatinine can be also used as a criterion of acceptability of the collected spot urine samples if its concentrations range between $0.3 \mathrm{~g} / \mathrm{L}$ to $3.0 \mathrm{~g} / \mathrm{L}$ [57]. In this study, urinary creatinine concentrations varied from 0.706 to $2.90 \mathrm{~g} / \mathrm{L}$ for NSNExp individuals, between 0.91 to $2.77 \mathrm{~g} / \mathrm{L}$ for SNExp firemen, and 0.700 to 2.95 for SExp subjects. No significant differences were found between the groups $(p>0.05)$. 1OHPhen was quantified in all samples, $10 \mathrm{HNaph}+10 \mathrm{HAce}, 2 \mathrm{HFlu}$, and $10 \mathrm{HPy}$ were determined in $97 \%$ of the urine samples. $30 \mathrm{HB}[\mathrm{a}] \mathrm{P}$ was never detected and thus it was excluded from the further analysis. Some authors have observed that PAHs with low molecular weight ( 2 and 3 aromatic rings, such as naphthalene, acenaphthene, fluorene, and phenanthrene) are predominantly eliminated as macromolecules conjugates through the urine $[4,5,23,58,59]$. Information related with pharmacokinetics of OH-PAHs is very scarce, reason why the elimination kinetics of PAH metabolites for each route of exposure remain unclear. For 1OHPy, the most characterized $\mathrm{OH}-\mathrm{PAH}$, the half-life excretion rate varies between 6 and $35 \mathrm{~h}[60,61]$, from $4.4-12 \mathrm{~h}[58,62]$ and up to $13 \mathrm{~h}[62-64]$ after inhalation, ingestion, and dermal exposures, respectively. For the other OH-PAHs, Li et al. [59] reported a half-life excretion rate of 3.3-6.2 $\mathrm{h}$ for $10 \mathrm{HNaph}, 2.3-4.0 \mathrm{~h}$ for 2OHFlu, and $4.3-6.1 \mathrm{~h}$ for 10HPhen for ingestion in non-smoking volunteers with no occupational exposure to PAHs. With increasing molecular weight of PAHs, the complexity of their metabolism also increases so metabolites of high molecular weight PAHs are predominantly eliminated through the feces rather than in urine [59,65]. Fernando et al. [34] detected 10HPy and 3-hydroxyfluoranthene in less than $50 \%$ of the total samples. Other authors have also reported very low detection rates for $3 \mathrm{OHB}[\mathrm{a}] \mathrm{P}$ in exposed (smoking and non-smoking) workers $[59,66,67]$.

\subsection{Impact of tobacco smoke}

The concentrations of individual compounds in NSNExp and SNExp groups, organized per fire station, are presented in Fig. 1. The levels of 1 OHNaph +1 OHAce $(0.033-0.98 \mu \mathrm{mol} / \mathrm{mol}$ creatinine; $0.138-4.19 \mu \mathrm{g} / \mathrm{L}$ urine), 10 HPhen $(0.002-0.077 \mu \mathrm{mol} / \mathrm{mol}$ creatinine; $0.007-0.362 \mu \mathrm{g} / \mathrm{L}$ urine), and 1 OHPy $(0.004-0.089 \mu \mathrm{mol} / \mathrm{mol}$ creatinine; $0.022-0.369 \mu \mathrm{g} / \mathrm{L}$ urine) (Fig. 1) determined in this study for NSNExp individuals were well below the reference values defined by the German Human Biomonitoring Commission for the general non-smoking population: $<30 \mu \mathrm{g} / \mathrm{L}$ urine for $10 \mathrm{HNaph}$ [68], $0.6 \mu \mathrm{g} / \mathrm{L}$ urine for 10 HPhen and $0.5 \mu \mathrm{g} / \mathrm{L}$ urine for $10 \mathrm{HPy}$ [68-70]. The levels were in a similar range as those reported by Haines et al. [71] for the Canadian population during the third cycle (2012-2013) of a large ongoing study (2007-2019) conducted by the Canadian Health Measure Surveys, and also in agreement with the concentrations previously reported for other NSNExp Portuguese firefighters [4]. In European countries, the consumption of any kind of tobacco was restricted and/or forbidden in enclosed public places, on public transport and in workplaces, with only limited exceptions allowed for some particular economic sectors [72]. Thus firefighters considered in this study were not exposed to 
M. Oliveira et al. / Journal of Hazardous Materials 334 (2017) 10-20

13
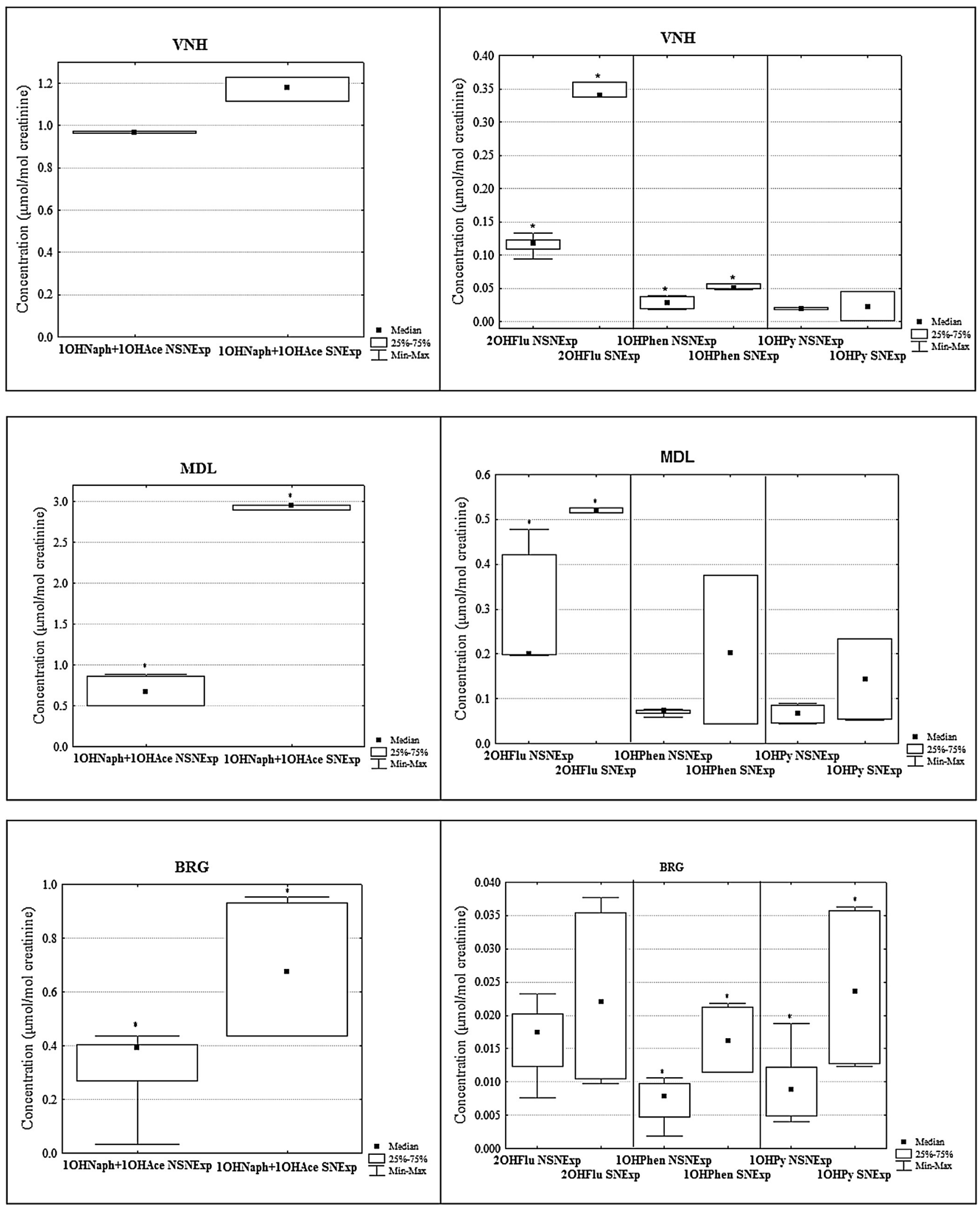

Fig. 1. Concentrations of urinary monohydroxyl-PAHs (median, $25-75$ percentiles and range; $\mu$ mol/mol creatinine; 10HNaph +10HAce: 1-hydroxynaphthalene and 1hydroxyacenaphthene; 2OHFlu: 2-hydroxyfluorene; 10HPhen: 1-hydroxyphenanthrene; 10HPy: 1-hydroxypyrene) determined in non-smoking non-exposed (NSNExp) and in smoking non-exposed (SNExp) firefighters' from three different fire stations (Vinhais (VNH), Mirandela (MDL), and Bragança (BRG)). 'Statistically significant differences at $p \leq 0.05$ between non-smoking non-exposed and smoking non-exposed firefighters (non-parametric Mann-Whitney $U$ test). The value of LOD/ $\sqrt{ } 2$ was used whenever the concentration of OH-PAHs was below the LOD [90]. 
Table 1

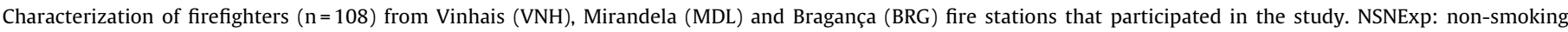
non-exposed; SNExp: smoking non-exposed; SExp: Smoking exposed individuals.

\begin{tabular}{|c|c|c|c|c|c|c|c|c|c|}
\hline \multirow[t]{2}{*}{ Characteristic } & \multicolumn{3}{|l|}{ VNH } & \multicolumn{3}{|l|}{ MDL } & \multicolumn{3}{|l|}{ BRG } \\
\hline & NSNExp & SNExp & SExp & NSNExp & SNExp & SExp & NSNExp & SNExp & SExp \\
\hline Firefighters (n) & 9 & 6 & 15 & 9 & 6 & 9 & 18 & 6 & 30 \\
\hline Age (mean $\pm S D ;$ min-max; years) & $\begin{array}{l}27 \pm 6.7 \\
(23-35)\end{array}$ & $\begin{array}{l}38 \pm 12 \\
(30-47)\end{array}$ & $\begin{array}{l}29 \pm 4.0 \\
(25-35)\end{array}$ & $\begin{array}{l}29 \pm 7.0 \\
(22-36)\end{array}$ & $\begin{array}{l}43 \pm 24 \\
(26-60)\end{array}$ & $\begin{array}{l}33 \pm 12 \\
(25-48)\end{array}$ & $\begin{array}{l}40 \pm 5.6 \\
(34-48)\end{array}$ & $\begin{array}{l}22 \pm 1.4 \\
(21-23)\end{array}$ & $\begin{array}{l}31 \pm 9.4 \\
(21-53)\end{array}$ \\
\hline $\begin{array}{l}\text { Body mass index (mean } \pm \mathrm{SD} \text {; } \\
\text { min-max; } \mathrm{kg} / \mathrm{m}^{2} \text { ) }\end{array}$ & $\begin{array}{l}24 \pm 3.2 \\
(21-26)\end{array}$ & $\begin{array}{l}22 \pm 3.3 \\
(19-24)\end{array}$ & $\begin{array}{l}23 \pm 1.7 \\
(21-24)\end{array}$ & $\begin{array}{l}29 \pm 5.0 \\
(26-35)\end{array}$ & $\begin{array}{l}24 \pm 1.2 \\
(23-25)\end{array}$ & $\begin{array}{l}22 \pm 2.8 \\
(19-25)\end{array}$ & $\begin{array}{l}29 \pm 4.2 \\
(25-36)\end{array}$ & $\begin{array}{l}26 \pm 2.4 \\
(24-28)\end{array}$ & $\begin{array}{l}26 \pm 2.3 \\
(22-29)\end{array}$ \\
\hline $\begin{array}{l}\text { Diastolic blood pressure } \\
\quad(\text { mean } \pm \text { SD; min-max; mmHg) }\end{array}$ & $\begin{array}{l}81 \pm 4.5 \\
(77-86)\end{array}$ & $\begin{array}{l}65 \pm 5.7 \\
(61-69)\end{array}$ & $\begin{array}{l}87 \pm 7.6 \\
(81-96)\end{array}$ & $\begin{array}{l}80 \pm 33 \\
(49-114)\end{array}$ & $\begin{array}{l}73 \pm 1.4 \\
(72-74)\end{array}$ & $\begin{array}{l}84 \pm 18 \\
(60-96)\end{array}$ & $\begin{array}{l}86 \pm 11 \\
(72-106)\end{array}$ & $\begin{array}{l}92 \pm 7.1 \\
(87-97)\end{array}$ & $\begin{array}{l}83 \pm 9.9 \\
(68-98)\end{array}$ \\
\hline $\begin{array}{l}\text { Systolic blood pressure } \\
\quad(\text { mean } \pm \mathrm{SD} ; \text { min-max; mmHg) }\end{array}$ & $\begin{array}{l}136 \pm 2.5 \\
(133-138)\end{array}$ & $\begin{array}{l}110 \pm 3.5 \\
(108-113)\end{array}$ & $\begin{array}{l}138 \pm 6.3 \\
(129-144)\end{array}$ & $\begin{array}{l}128 \pm 9.7 \\
(120-139)\end{array}$ & $\begin{array}{l}127 \pm 0.71 \\
(127-128)\end{array}$ & $\begin{array}{l}132 \pm 23 \\
(113-156)\end{array}$ & $\begin{array}{l}137 \pm 11 \\
(127-152)\end{array}$ & $\begin{array}{l}138 \pm 19 \\
(125-152)\end{array}$ & $\begin{array}{l}132 \pm 11 \\
(118-150)\end{array}$ \\
\hline $\begin{array}{l}\text { Cardiac frequency (mean } \pm \mathrm{SD} \\
\min -\mathrm{max} ; \text { heart beats/min) }\end{array}$ & $\begin{array}{l}69 \pm 9.9 \\
(58-76)\end{array}$ & $\begin{array}{l}73 \pm 1.4 \\
(72-74)\end{array}$ & $\begin{array}{l}74 \pm 16 \\
(54-87)\end{array}$ & $\begin{array}{l}76 \pm 25 \\
(56-105)\end{array}$ & $\begin{array}{l}77 \pm 1.4 \\
(76-78)\end{array}$ & $\begin{array}{l}83 \pm 19 \\
(54-112)\end{array}$ & $\begin{array}{l}72 \pm 9.4 \\
(62-84)\end{array}$ & $\begin{array}{l}79 \pm 5.7 \\
(75-83)\end{array}$ & $\begin{array}{l}78 \pm 12 \\
(64-101)\end{array}$ \\
\hline $\begin{array}{l}\text { Arterial oxigen saturation } \\
\quad(\text { mean } \pm \text { SD; min-max; \%) }\end{array}$ & $\begin{array}{l}98 \pm 1.2 \\
(97-99)\end{array}$ & $99^{a}$ & $\begin{array}{l}98 \pm 0.7 \\
(97-99)\end{array}$ & $99^{\mathrm{a}}$ & $\begin{array}{l}97 \pm 0.7 \\
(97-98)\end{array}$ & $\begin{array}{l}98 \pm 0.6 \\
(97-99)\end{array}$ & $\begin{array}{l}97 \pm 1.2 \\
(95-98)\end{array}$ & $\begin{array}{l}97 \pm 0.7 \\
(97-98)\end{array}$ & $\begin{array}{l}97 \pm 1.4 \\
(95-99)\end{array}$ \\
\hline Respiratory pathologies (n) & No & $\begin{array}{l}1 \\
\text { rhinitis; } \\
\text { sinusitis } \\
\text { allergic to } \\
\text { pollens, } \\
\text { dust, dust } \\
\text { mites, } \\
\text { varnishes }\end{array}$ & No & $\begin{array}{l}2 \\
\text { sinusitis }\end{array}$ & No & No & $\begin{array}{l}1 \\
\text { sinusitis }\end{array}$ & No & No \\
\hline $\begin{array}{l}\text { Number of cigarettes smoked per } \\
\text { day (mean } \pm S D ; \text { min-max) }\end{array}$ & n.a. & $\begin{array}{l}8 \pm 3 \\
(6-10)\end{array}$ & $\begin{array}{l}21 \pm 2.2 \\
(20-25)\end{array}$ & n.a. & $\begin{array}{l}15 \pm 7.1 \\
(10-20)\end{array}$ & $\begin{array}{l}16 \pm 7.6 \\
(5-25)\end{array}$ & n.a. & $\begin{array}{l}11 \pm 1.4 \\
(10-12)\end{array}$ & $\begin{array}{l}16 \pm 5.6 \\
(4-20)\end{array}$ \\
\hline Number of years as firefighters & & & & & & & & & \\
\hline$\leq 10$ years $(\%)$ & 33 & 50 & 20 & 33 & 50 & 67 & 17 & 100 & 70 \\
\hline $10-20$ years $(\%)$ & 67 & 50 & 80 & 67 & 0 & 0 & 33 & 0 & 20 \\
\hline$\geq 20$ years $(\%)$ & 0 & 0 & 0 & 0 & 50 & 33 & 50 & 0 & 10 \\
\hline $\begin{array}{l}\text { Time dedicated to firefighting } \\
\text { activities ( } 48 \mathrm{~h} \text { before sampling; } \\
\text { mean } \pm \mathrm{SD} ; \text { min-max; } \mathrm{h} \text { ) }\end{array}$ & n.a. & n.a. & $\begin{array}{l}3.2 \pm 1.1 \\
(2-4)\end{array}$ & n.a. & n.a. & $\begin{array}{l}2.0 \pm 0.6 \\
(1-4)\end{array}$ & n.a. & n.a. & $\begin{array}{l}3.1 \pm 2.2 \\
(0.5-8)\end{array}$ \\
\hline
\end{tabular}

na - Not applicable.

a All firefighters from this group presented the same value of arterial oxygen saturation at the end of their work shift.

environmental tobacco smoke in the facilities of the respective fire stations. Non-smoking firefighters also reported in their questionnaire that they were not exposed to environmental tobacco smoke outside of their fire corporation in the week preceding the urine collections. The quantification of urinary cotinine, the principal metabolite of nicotine (biomarker of exposure to tobacco smoke) allows validating data (obtained by the questionnaires) concerning the smoking habits of firefighters; however, it was not determined in this study. Still, there is generally a high concordance level between the information reported in the questionnaires of smoking industrial workers and the urinary concentrations of cotinine [73], being the differences observed between NSNExp and SNExp firefighters attributed to tobacco consumption. Also, it should be taken in consideration that the studied individuals reported diets exclusive of charbroiled and deep-fried foods within the five days before urine collection, so the contribution of food to the overall PAHs exposure can be considered as negligible.

Levels of total OH-PAHs ( $\sum \mathrm{OH}-\mathrm{PAHs}$ ) in Portuguese firefighters are exhibited in Table 2. At the three fire stations, the median concentrations of individual (Fig. 1) and total (Table 2) compounds in SNExp were overall higher than in NSNExp subjects. Urinary concentrations of $10 \mathrm{HNaph}+10 \mathrm{HAce}$ for SNExp firefighters were increased from 22\% (VNH: 0.097 versus $1.18 \mu \mathrm{mol} / \mathrm{mol}$ creatinine; $p>0.05$ ) to 339\% (MDL: 0.67 versus $2.96 \mu \mathrm{mol} / \mathrm{mol}$ creatinine; $p=0.024$ ) comparatively with NSNExp individuals. The urinary levels of the other PAH metabolites followed the same tendency: $29 \%$ (BRG: 0.017 versus $0.022 \mu \mathrm{mol} / \mathrm{mol}$ creatinine; $p>0.05$ ) to $188 \%$ (VNH: 0.118 versus $0.340 \mu \mathrm{mol} / \mathrm{mol}$ creatinine; $p=0.009$ ) for 2OHFlu, 76\% (VNH: 0.029 versus $0.051 \mu \mathrm{mol} / \mathrm{mol}$ creatinine; $p=0.002$ ) to $176 \%$ (MDL: 0.074 versus $0.204 \mu \mathrm{mol} / \mathrm{mol}$ creatinine; $p>0.05$ ) for $10 H P h e n$, and $20 \%$ (VNH: 0.020 versus $0.024 \mu \mathrm{mol} / \mathrm{mol}$ creatinine; $p>0.05$ ) to $167 \%$ (BRG: 0.009 versus $0.024 \mu \mathrm{mol} / \mathrm{mol}$
Table 2

Total urinary PAH metabolites ( $\sum \mathrm{OH}-\mathrm{PAHs}$ ) concentrations (median and range; $\mu \mathrm{mol} / \mathrm{mol}$ creatinine) determined in non-smoking non-exposed (NSNExp), smoking non-exposed (SNExp), and smoking exposed (SExp) firefighters from the selected fire stations: Vinhais (VNH), Mirandela (MDL) and Bragança (BRG).

\begin{tabular}{llll}
\hline \multirow{2}{*}{ Fire station } & \multicolumn{4}{l}{$\sum$ OH-PAHs $(\mu \mathrm{mol} / \mathrm{mol}$ creatinine $)$} \\
\cline { 2 - 4 } & NSNExp & SNExp & SExp \\
\hline VNH & 0.16 & $0.82^{*}$ & $5.34^{*}$ \\
& $(0.12-1.12)$ & $(0.05-1.67)$ & $(2.20-8.59)$ \\
MDL & 0.82 & $2.06^{*}$ & $5.71^{*}$ \\
& $(0.56-1.24)$ & $(0.59-3.59)$ & $(5.44-5.94)$ \\
BRG & $0.42^{\#}$ & $0.74^{\#, *}$ & $1.91^{*}$ \\
& $(0.05-0.47)$ & $(0.49-1.02)$ & $(0.09-52.4)$ \\
\hline
\end{tabular}

\# Statistically significant $(p<0.05)$ between non-smoking non-exposed and smoking non-exposed firefighters.

Statistically significant $(p<0.05)$ between smoking non-exposed and smoking exposed firefighters.

creatinine; $p=0.005$ ) for 10 HPy (Fig. 1). Feunekes et al. [37] also found concentrations of 10 HPy that were $213 \%$ higher in the urine of smokers compared with non-smoking firefighters ( 0.47 versus $0.15 \mu \mathrm{mol} / \mathrm{mol}$ creatinine; $p=0.01$ ) during a set of controlled fires in a confined training area. Overall, tobacco consumption promoted a $\sum \mathrm{OH}-\mathrm{PAH}$ concentration increase of $76 \%$ (BRG) to $412 \%(\mathrm{VNH})$ (Table 2). In agreement, Fernando et al. [34] previously reported higher levels of urinary OH-PAHs for smoking firefighters during training exercises at Canadian burn houses. In addition, the majority of available studies (mostly non-occupational ones) also concluded that smokers possess higher levels of urinary OH-PAHs than non-smoking subjects $[74,75]$, which may be attributed to the occurrence of genetic polymorphisms in the carcinogen metabolizing enzymes $[15,74]$. Benzo[a]pyrene, the only known human 

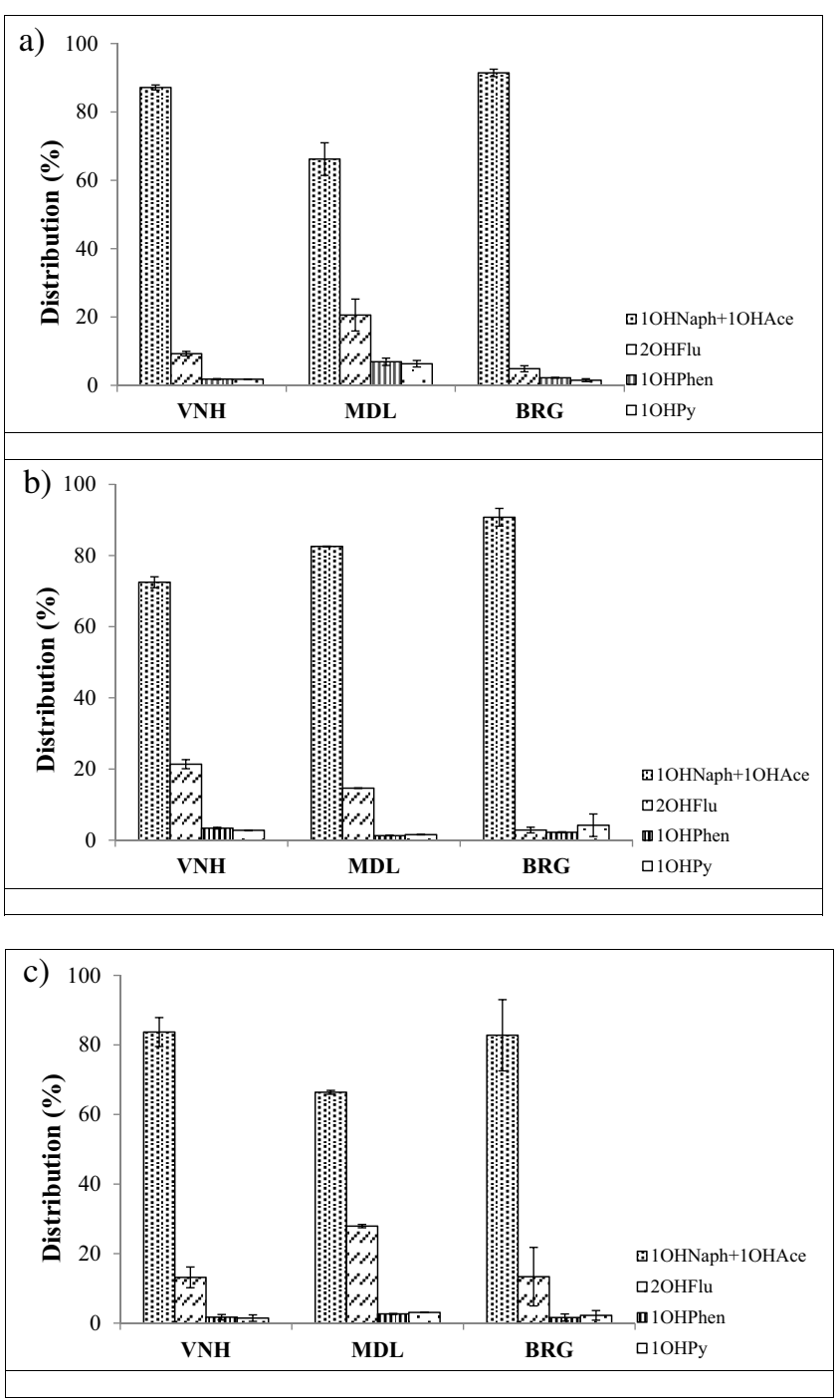

Fig. 2. Distribution of monohydroxyl-PAHs (10HNaph +10HAce: 1hydroxynaphthalene and 1-hydroxyacenaphthene; 20HFlu: 2-hydroxyfluorene; 10HPhen: 1-hydroxyphenanthrene; 10HPy: 1-hydroxypyrene) in the urine of non-smoking non-exposed firefighters (a), smoking non-exposed (b) and smoking exposed (c) firefighters from different fire stations (Vinhais (VNH), Mirandela (MDL), and Bragança (BRG)).

carcinogenic PAH [17] has been detected in cigarette smoke only in small quantities and therefore it is difficult to detect its metabolites in the urine of smoking people [15,61]. Haines et al. [71] detected benzo[a]pyrene, chrysene, and fluoranthene metabolites in less than $2 \%$ of the urine samples collected in Canadian citizens within the Canadian Health Measures Survey during the third cycle of the study. No significant differences were observed between the distribution profiles of OH-PAHs in NSNExp and SNExp subjects, with 1 OHNaph +1 OHAce accounting for $66-91 \%$ of $\sum \mathrm{OH}-\mathrm{PAHs}$, followed by $2 \mathrm{OHFlu}$ (4.9-21\%), 10HPhen (1.8-6.9\%), and $10 \mathrm{HPy}$ (1.5-6.3\%) (Fig. 2a and b). Still, Lu and Zhu [76] described a similar profile for 17 airborne PAHs in the tobacco smoke of 12 commercial brand cigarettes (2-3 aromatic rings accounted with $74 \%$ of $\Sigma$ PAHs; 4-ring compounds represented $11 \%$ of $\Sigma$ PAHs and PAHs with 5 and more aromatic rings contributed with $15 \%$ of $\Sigma$ PAHs).

The relation between the urinary levels of individual and total OH-PAHs with the number of smoked cigarettes for each SNExp subject was explored through the determination of Spearman correlation coefficients $(r)$. The attained correlations were predominantly medium to high $(r \geq 0.878$ and $p \leq 0.021$ at $B R G ; r \geq 0.603$ and $p \leq 0.205$ at $\mathrm{VNH} ; \mathrm{r}=0.878$ and $p \leq 0.021$ at MDL, except for $10 \mathrm{HNaph}+10 \mathrm{HAce}$ and 2OHFlu at VNH and MDL fire corporations). Hagedorn et al. [74] also observed significant correlations $(\mathrm{r}=0.34-0.63$ and $p<0.001)$ between the levels of urinary OH-PAHs with the daily cigarette consumption in smokers, revealing that smokers of cigarettes with higher tar yield excreted significantly higher amounts of urinary 1 - and 2OHNaph, 2OHFlu, 1 +9OHPhen, $2+30$ HPhen, and 10HPy than non-smokers.

\subsection{Impact of fire emissions}

Since no significant differences were observed between the number of cigarettes consumed by SNExp and SExp firefighters $(p>0.05)$, these two groups were used to study the influence of fire emissions on firefighter's $\Sigma$ PAHs exposure. Fig. 3 presents the median concentrations of each $\mathrm{OH}-\mathrm{PAH}$ and the respective ranges for SNExp and SExp firefighters per station, while the respective distribution (\%) is exhibited in Fig. 2(b and c). Firemen who were directly involved in wildland fire combats reported the use of self-protective equipment with flame-retardant properties, helmet with eye protection, flashhood and gloves, as required by the Portuguese legislation [77]. However, the urinary median concentrations of individual (Fig. 3) and $\sum \mathrm{OH}-\mathrm{PAHs}$ (Table 2) was overall higher in SExp than in SNExp firefighters. 1OHNaph + 10HAce were by far the most predominant OH-PAHs, accounting for $72-91 \%$ and $66-84 \%$ of $\sum \mathrm{OH}-\mathrm{PAHs}$ for (smoking) non-exposed and exposed subjects, respectively (Fig. 2b and c). Their concentrations increased between $48 \%$ (MDL: 2.96 versus $4.38 \mu \mathrm{mol} / \mathrm{mol}$ creatinine) and 268\% (VNH: 1.18 versus $4.35 \mu \mathrm{mol} / \mathrm{mol}$ creatinine) for SExp firefighters compared with SNExp subjects ( $p \leq 0.024$; Fig. 3 ). 2OHFlu was the second most abundant PAH metabolite $\left(2.8-21 \%\right.$ of $\sum \mathrm{OH}-$ PAHs for SNExp and 13-28\% for SExp firefighters), followed by $1 \mathrm{OHPy}(1.5-4.2 \%$ versus $1.4-3.1 \%)$ and 10 HPhen $(1.3-3.4 \%$ versus 1.6-2.6\%). Urinary 2OHFlu was the compound with the highest increment in SExp individuals, increasing from 111\% (VNH: 0.340 versus $0.718 \mu \mathrm{mol} / \mathrm{mol}$ creatinine; $p=0.031$ ) to $1068 \%$ (BRG: 0.022 versus $0.257 \mu \mathrm{mol} / \mathrm{mol}$ creatinine; $p \leq 0.001$ ) while 1 OHPy (83\% (BRG: 0.044 versus $0.024 \mu \mathrm{mol} / \mathrm{mol}$ creatinine, $p=0.001$ ) to 220\% (MDL: 0.462 versus $0.144 \mu \mathrm{mol} / \mathrm{mol}$ creatinine, $p>0.05$ )) and 1 OHPhen were the least affected (87\% (BRG: 0.016 versus $0.030 \mu \mathrm{mol} / \mathrm{mol}$ creatinine; $p=0.005$ ) to $112 \%$ (VNH: 0.051 versus $0.108 \mu \mathrm{mol} / \mathrm{mol}$ creatinine; $p>0.05$ )) by firefighters's exposure to emissions released during firefighting activities (Fig. 3 ). These findings are in accordance with the small but significant increase of $10 H P y$ concentrations determined in the urine of 13 individuals at a firefighting training school [38]. Edelman et al. [36] reported urinary $1-, 2-$, and 30HPhen and 10HPy increments ranging from 22 to $61 \%$ and 76 to $81 \%$ in firemen who actively participated in firefighting activities during and after the World Trade Center collapse. Laitinen et al. [11] also observed urinary 10HPy concentrations that were 50-537\% higher in European firefighting trainers at gas and fire house diving simulators. More recently, Fernando et al. [34] found significantly elevated concentrations (up to 40-fold increase when compared with the baseline, $0.6 \mu \mathrm{g} / \mathrm{g}$ of creatinine) of total post exposure urinary $1-$ and 2OHNaph, 2-, 3-, and 9OHFlu, and $2-, 3-$, and 4OHPhen in 25 firefighters during training exercises at Canadian burn houses; similar trend was also reported by Oliveira et al. [5] for non-smoking firefighters that were directly involved in fire combat (knockdown and overhaul). BRG was the fire station where the differences between SNExp and SExp individuals were all statistically significant for individual (Fig. 3c) and total (Table 2) OH-PAHs $(p \leq 0.05)$. Within the SExp firefighters serving at BRG fire corporation, three individuals presented much higher levels of 1 OHNaph +1 OHAce $(49.6-52.2 \mu \mathrm{mol} / \mathrm{mol}$ creatinine) in comparison with the other exposed colleagues; no specific source was identified to justify these higher levels. The median $\sum \mathrm{OH}-$ 

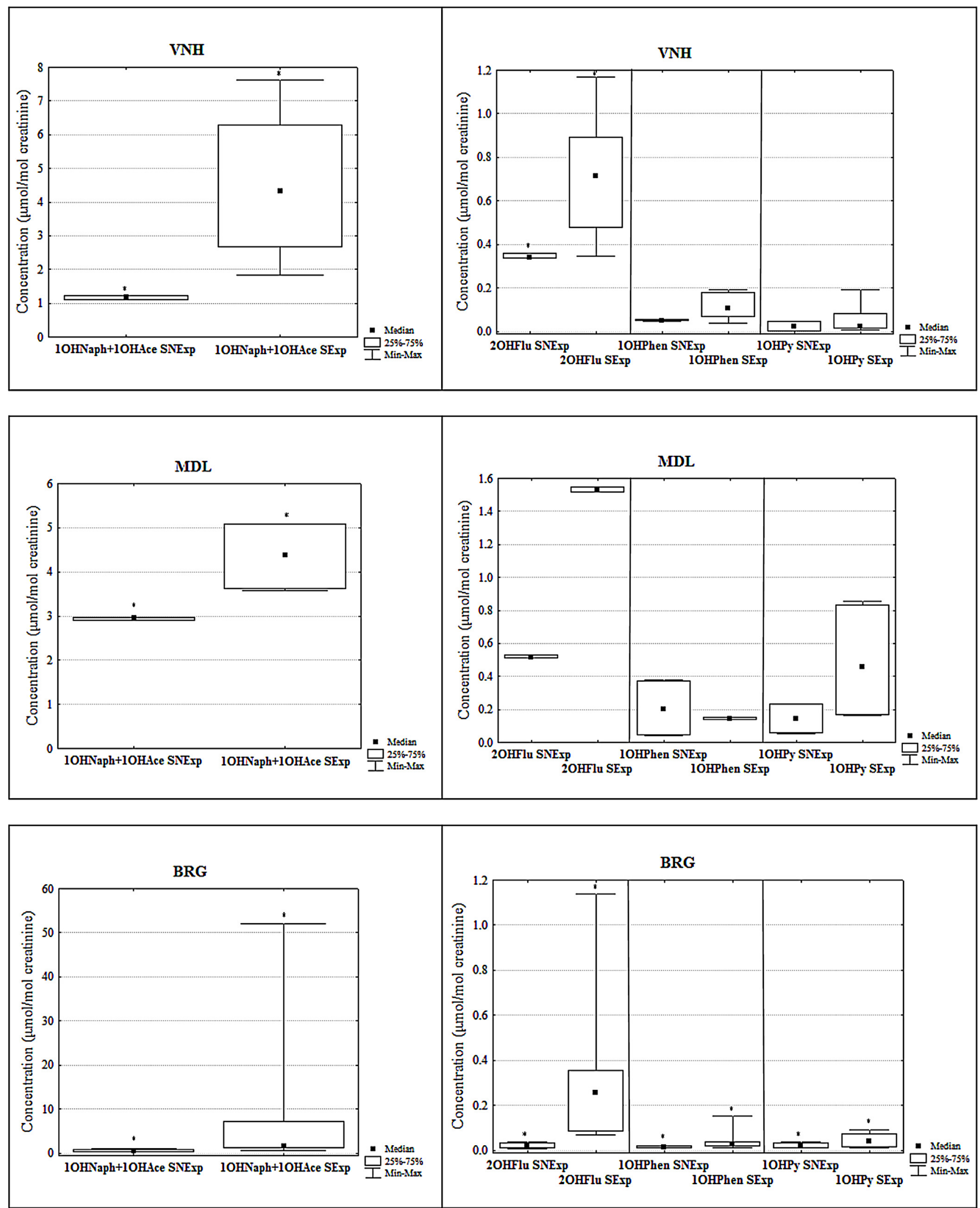

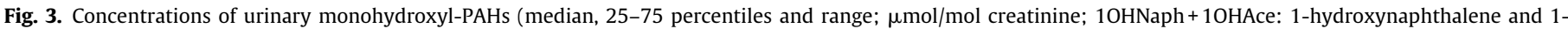

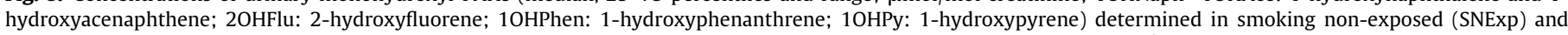

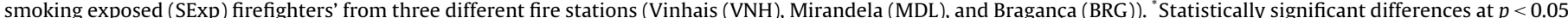

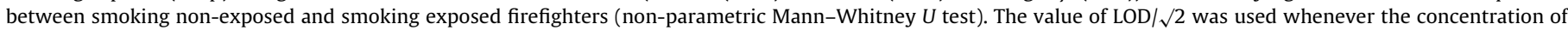
$\mathrm{OH}-\mathrm{PAH}$ was below the LOD [90]. 
PAH concentrations ranged between 0.74 (BRG) and $2.06 \mu \mathrm{mol} / \mathrm{mol}$ creatinine (MDL) for SNExp and from 1.91 (BRG) to $5.71 \mu \mathrm{mol} / \mathrm{mol}$ creatinine (MDL) for SExp (Table 2). The determined levels of $\sum \mathrm{OH}-$ PAHs increased between 158 (BRG) and 551\% (VNH) $(p \leq 0.02)$ in exposed firemen, reflecting the impact of firefighting activities on the total PAHs exposure (Table 2).

The inter-relation between individual and total OH-PAHs was also estimated. Overall, moderate to strong correlations were observed among individual compounds and between individual OH-PAHs with $\sum \mathrm{OH}-\mathrm{PAHs}$ for SExp individuals working at $\mathrm{VNH}(\mathrm{r} \geq 0.737 ; p \leq 0.006$, except between 10HPhen with 10 HNaph +10 HAce and with $\left.\sum \mathrm{OH}-\mathrm{PAHs}\right)$ and BRG $(\mathrm{r} \geq 0.514$; $p \leq 0.050$, except between 2OHFlu and 1OHNaph +10 HAce and with 1OHPy) fire stations. These findings indicated the predominant impact of common sources of PAHs exposure. In addition, the correlation between the urinary levels of individual and $\mathrm{\Sigma OH}-\mathrm{PAHs}$ with the number of hours that each firefighter dedicated to combat activities were also estimated. In general, moderate to strong correlations were observed for all firefighters from the characterized fire stations: $r \geq 0.760$ and $p \leq 0.028$ at $\mathrm{VNH} ; \mathrm{r} \geq 0.878$ and $p \leq 0.021$ except for 2OHFlu and 1OHPhen at MDL; $r \geq 0.413$ and $p \leq 0.023$ except for 1 OHNaph +1 OHAce and 1 OHPy at BRG. These results show the influence of participation in fire combat activities on $\Sigma$ PAHs exposure of firemen. Despite the short period of exposure, the use of self-protective equipment revealed to be insufficient to protect firemen from the emissions released during fires and thus preventive action measures should be implemented to reduce inhalation and dermal exposure to PAHs during fire combat.

In a view of the scarce information regarding firefighters' occupational exposure, comparison with the reported results is extremely difficult. Furthermore, the reported data are frequently not normalized with creatinine concentrations [11,33,36]. Still, the urinary levels of 10HPy in SExp firefighters (overall range: $0.025 \mu \mathrm{mol} / \mathrm{mol}$ creatinine at VNH to $0.462 \mu \mathrm{mol} / \mathrm{mol}$ creatinine at MDL) were lower than those reported for 43 Canadian firefighters involved in a fire combat $(0.080-3.63 \mu \mathrm{mol} / \mathrm{mol}$ creatinine; [31]). The concentrations in SExp firefighters determined in this study were overall higher than the levels observed for NSNExp firefighters serving at other Portuguese fire stations [5].

Limited information is available concerning the reference standards and guidelines for urinary levels of OH-PAHs. In 2010, the American Conference of Governmental Industrial Hygienists recommended a 1OHPy limit of $0.5 \mu \mathrm{mol} / \mathrm{mol}$ creatinine for occupational PAHs exposure [78]. Only three exposed firefighters from MDL fire station exceeded that reference guideline, the urinary $\mathrm{OH}-$ PAH concentrations of those firemen being much lower than the no-biological effect limit of $1.4 \mu \mathrm{mol} / \mathrm{mol}$ creatinine proposed by Jongeneelen [29].

\subsection{Cumulative effects of tobacco smoke and fire emissions}

The majority of occupational health effects, including the development of cancers, are predominantly caused by exposure to a multiple causal factors rather than to a specific agent; as a consequence, people exposed to more than one risk factor are more prompt to present the symptoms and develop the illness. Smoking firefighters are simultaneously exposed to the potential health effects of tobacco consumption and the hazardous fire emissions. In comparison with NSNExp firefighters, the urinary concentrations of $\sum \mathrm{OH}-\mathrm{PAH}$ in SExp individuals increased from 355\% (BRG: 1.91 versus $0.42 \mu \mathrm{mol} / \mathrm{mol}$ creatinine; $p \leq 0.001$ ) to $3237 \%$ (VNH: 5.34 versus $0.16 \mu \mathrm{mol} / \mathrm{mol}$ creatinine; $p \leq 0.001$ ) (Table 2). The median urinary concentrations of individual compounds were augmented as high as 308\% (BRG: $0.394 \mu \mathrm{mol} / \mathrm{mol}$ creatinine in NSNExp subjects versus $1.61 \mu \mathrm{mol} / \mathrm{mol}$ creatinine in SExp; $p \leq 0.001$ ) to $550 \%$ (MDL: 0.674 versus $4.38 \mu \mathrm{mol} / \mathrm{mol}$ crea- tinine; $p=0.002)$ for $10 H N a p h+10 H A c e$, from $508 \%(\mathrm{VNH}$ : 0.118 versus $0.718 \mu \mathrm{mol} / \mathrm{mol}$ creatinine; $p \leq 0.001$ ) to $1412 \%$ (BRG: 0.017 versus $0.257 \mu \mathrm{mol} / \mathrm{mol}$ creatinine; $p \leq 0.001$ ) for $2 \mathrm{OHFlu}$, and from 97\% (MDL: 0.074 versus $0.146 \mu \mathrm{mol} / \mathrm{mol}$ creatinine; $p=0.009$ ) to 275\% (BRG: 0.008 versus $0.030 \mu \mathrm{mol} / \mathrm{mol}$ creatinine; $p \leq 0.001$ ) for 10 HPhen. Urinary $10 H$ Py presented a similar trend with increments ranging between $25 \%$ (VNH: 0.020 versus $0.025 ; p>0.05$ ) to $579 \%$ (MDL: 0.068 versus $0.462 \mu \mathrm{mol} / \mathrm{mol}$ creatinine; $p \leq 0.001$ ). The increments in the urinary levels of $\mathrm{OH}-\mathrm{PAHs}$ reflect the potential cumulative effects of smoking consumption and occupational activities to the total PAHs exposure. In general, urinary 2OHFlu and 10 HNaph +10 HAce were the most affected compounds by the impact of both factors. The Bartlett sphericity test showed that these metabolites were strongly correlated with each other $(\mathrm{r}=0.600 ; p<0.001)$. Principal component analysis (PCA) was performed based on urinary concentrations of those two OH-PAHs for NSNExp, SNExp, and SExp firefighters (Fig. 2S, Supplementary material). The Kaiser-Meyer-Olkin values were $\geq 0.5$ for both variables. The first function (F1) issued from PCA explained up to $80.01 \%$ of the total variance, presenting the highest loadings for both variables (square cosines values $>0.800$ ). It allowed the differentiation of the majority of SExp and NSNEXP firefighters from the others, highlighting the discriminating power of urinary 10 HNaph + 10HAce and 2OHFlu. The second function (F2) contributed with $19.99 \%$ of the original data. NSNEXP subjects are grouped together with mostly negative F1 and (or near zero) F2 scores. Still, a higher number of subjects would be precious to corroborate the findings achieved in this study.

Previously, Feunekes et al. [37] also found significant influences of both tobacco smoking and exposure to smoke released during fires on the urinary levels of 10HPy in trainers and instructors from a firefighting school. More recently, Fernando et al. [34] observed higher levels of urinary OH-PAHs and methoxyphenols in smoking firefighters compared with non-smoking subjects working at four Canadian fire stations during training exercises at burn houses. The concentrations of urinary OH-PAHs in Portuguese SExp firefighters were mainly much lower than the levels reported for other relevant occupations concerning PAHs exposure, such as coke-oven workers, iron foundry and aluminum production workers, mining workers, as well as employees from graphite electrodes, refractory materials, and special carbon products industrial productions $[67,73,79,80]$.

Little information is available concerning the impact of shortand long-term exposure to fire emissions in firefighters' health. It has been reported that cardiovascular disease is the leading cause of excess morbidity and mortality in firefighters $[9,42,43]$. Some investigators have notice a higher incidence of respiratory and pulmonary symptoms as well as airways hyper-responsiveness and decay in lung function of firefighters during fire combat activities $[9,81,82]$. In addition, tobacco smoke is associated with the development of lung cancer among other types of cancers and diseases, namely leukemia and cancers of the urinary and aerodigestive tracts as well as of stomach, pancreas, liver, breast, prostate, and colorectal tissues [15]. Some authors have also described an increased risk of developing respiratory, inflammatory and cardiovascular illnesses in smokers [83-85]. Thus SExp firefighters are more vulnerable to the development and/or aggravation of cardiorespiratory diseases; cumulative and synergistic effects may occur. Certain life styles may also potentiate the health risks associated with firefighters' exposure to PAHs. Indeed, PAHs are electrophilic substances that have been associated with cardiovascular disease and adverse reproductive outcomes [86]. Unmetabolized PAHs are known for their teratogenic, mutagenic, and carcinogenic properties and therefore constitute a serious threat to the health of humans $[19,20]$. Positive association between the urinary levels of 1OHNaph, 2OHNaph, 2OHPhen and total low molecular weight OH- 
PAHs with diabetes mellitus have also been reported in American adults [87]. Moreover, significant associations have been described between the levels of urinary 10HPy with asymmetric dimethylarginine in the plasma and also with adipocyte-fatty acid binding protein present in the serum of Mexican women [27,28]. However, the major concern is the ability of PAH reactive metabolites (in the form of epoxides and dihydrodiols) to bind to some proteins and DNA molecules, thus leading to biochemical disruptions and cell damage that may originate mutations, tumors and cancers [88]. Regarding the incidence of cancer in firefighters, some studies reported an elevated risk of developing several types of cancers, including urothelial, skin, lung, kidney and testicular cancers throughout their professional career; however, some findings remain contradictory [89-91].

\section{Conclusions}

This study assessed the total exposure to PAHs in three different groups of wildland firefighters (NSNExp, SNExp, and SExp) serving at three Portuguese fire stations through the determination of six urinary metabolites. SExp individuals presented levels of $\sum \mathrm{OH}-$ PAHs that were 355-3237\% higher than for NSNExp subjects, with occupational exposure to fire combat activities promoting significant increments of $158-551 \%$ in $\sum \mathrm{OH}-\mathrm{PAHs}$. Tobacco consumption increased 76-412\% the levels of $\sum \mathrm{OH}-\mathrm{PAHs}$ for SNExp firefighters. The main findings of this research indicated that individual and cumulative PAHs exposure occurs by participation in firefighting activities and tobacco consumption. More studies concerning both occupational exposure and characterization of other causal factors in firefighters, as well as, toxicological and epidemiological studies are needed to better estimate the overall risks and the potential health effects of firefighter's exposure to PAHs.

\section{Acknowledgments}

Authors are grateful for the cooperation with Escola Superior de Saúde-Instituto Politécnico de Bragança and particularly from all participants. This work received financial support from European (FEDER funds through COMPETE) and National (Fundação para a Ciência e Tecnologia project UID/QUI/50006/2013) funds and in the scope of the P2020 Partnership Agreement Project POCI-01-0145-FEDER-006939 (LEPABE) funded by FEDER funds through COMPETE2020. M Oliveira and K. Slezakova are also grateful for their fellowships, SFRH/BD/80113/2011 and SFRH/BPD/105100/2014, respectively.

\section{Appendix A. Supplementary data}

Supplementary data associated with this article can be found, in the online version, at http://dx.doi.org/10.1016/j.jhazmat.2017.03. 057.

\section{References}

[1] A.M. Hansen, L. Mathiesen, M. Pedersen, L.E. Knudsen, Urinary 1-hydroxypyrene (1-HP) in environmental and occupational studies-a review, Int. J. Hyg. Environ. Health 211 (2008) 471-503.

[2] A. Kamal, M. Qayyum, I.U. Cheema, A. Rashid, Biological monitoring of blood naphthalene levels as a marker of occupational exposure to PAHs among auto-mechanics and spray painters in Rawalpindi, BMC Public Health 11 (2011) 467-476.

[3] H. Levine, T. Berman, R. Goldsmith, T. Göen, J. Spungen, L. Novack, et al., Urinary concentrations of polycyclic aromatic hydrocarbons in Israeli adults: demographic and life-style predictors, Int. J. Hyg. Environ. Health 218 (2015) 123-131

[4] M. Oliveira, K. Slezakova, M.J. Alves, A. Fernandes, J.P. Teixeira, C. Delerue-Matos, et al., Polycyclic aromatic hydrocarbons at fire stations: firefighters' exposure monitoring and biomonitoring, and assessment of the contribution to total internal dose, J. Hazard. Mater. 322 (2017) 357-369.
[5] M. Oliveira, K. Slezakova, M.J. Alves, A. Fernandes, J.P. Teixeira, C. Delerue-Matos, et al., Firefighters' exposure biomonitoring: impact of firefighting activities on levels of urinary monohydroxyl metabolites, Int. J. Hyg. Environ. Health 219 (2016) 857-866.

[6] IARC Monographs on the Evaluation of Carcinogenic Risks to Humans: Painting, Firefighting and Shiftwork, vol. 98, International Agency for Research on Cancer, Lyon, France, 2010.

[7] NIOSH Pocket Guide to Chemical Hazards, U.S. Department of Health and Human Services, Public Health Service, Centers for Disease Control and Prevention. National Institute for Occupational Safety and Health, Cincinnati, Ohio, 2007.

[8] K.W. Fent, J. Eisenberg, D. Evans, D. Sammons, S. Robertson, C. Striley, et al., Evaluation of dermal exposure to polycyclic aromatic hydrocarbons in fire fighters, in: Health Hazard Evaluation Report No. 2010-0156-3196, United States Department of Health and Human Services, Centers for Disease Control and Prevention, National institute for Occupational Safety and Health, 2013.

[9] D.M. Gaughan, C.A. Piacitelli, B.T. Chen, B.F. Law, M.A. Virji, N.T. Edwards, et al., Exposures and cross-shift lung function declines in wildland firefighters, J. Occup. Environ. Hyg. 11 (2014) 591-603.

[10] J.-F. Hsu, H.-R. Guo, H.W. Wang, C.-K. Liao, P.-C. Liao, An occupational exposure assessment of polychlorinated dibenzo-p-dioxin and dibenzofurans in firefighters, Chemosphere 83 (2011) 1353-1359.

[11] J. Laitinen, M. Mäkelä, J. Mikkola, I. Huttu, Fire fighting trainers' exposure to carcinogenic agents in smoke diving simulators, Toxicol. Lett. 192 (2010) $61-65$.

[12] J.-S. Park, R.W. Voss, S. McNeel, N. Wy, T. Guo, Y. Wang, et al., High exposure of California firefighters to polybrominated diphenyl ethers, Environ. Sci. Technol. 49 (2015) 2948-2958.

[13] J.D. Pleil, M.A. Stiegel, K.W. Fent, Exploratory breath analysis for assessing toxic dermal exposures of firefighters during suppression of structural burns, J. Breath. Res. 8 (2014) 037107

[14] C.E. Reid, M. Brauer, F. Johnston, M. Jerrett, J.R. Balmes, C.T. Elliott, Critical review of health impacts of wildfire smoke exposure, Environ. Health Perspect. 124 (2016) 1334-1343.

[15] IARC Monographs on the Evaluation of Carcinogenic Risks to Humans: Tobacco Smoke and Involuntary Smoking, vol. 83, International Agency for Research on Cancer, 2004, pp. 1-1492.

[16] World Health Organization, Air Quality Guidelines, Second ed., WHO Regional Publications, European Series No. 91, Copenhagen, 2000.

[17] Directive of the European Parliament and the Council relating to arsenic, cadmium, mercury, nickel and polycyclic aromatic hydrocarbons in ambient air. Directive 2004/107/EC. Off. J. Eur. Union. L 23 (2005) 3-16.

[18] US Environmental Protection Agency, Guidelines for Carcinogen Risk Assessment, EPA/630/P-03/001F, US Environmental Protection Agency, Washington, D.C, 2005, http://www.epa.gov/raf/publications/pdfs/CANCER GUIDELINES_FINAL_3-25-05.pdf. (Accessed 25 September 2016).

[19] IARC Monographs on the Evaluation of the Carcinogenic Risks to Humans: Naphthalene, vol. 82, World Health Organization, International Agency for Research on Cancer, Lyon, France, 2002.

[20] IARC Monographs on the Evaluation of the Carcinogenic Risks to Humans: Some Non-Heterocyclic Polycyclic Aromatic Hydrocarbons and Some Related Exposures, vol. 92, International Agency for Research on Cancer, 2010, pp. $1-853$.

[21] World Health Organization, State of the Science of Endocrine Disrupting Chemicals 2012, United Nations Environment Programme and the World Health Organization, Geneva, 2013.

[22] A. Kamal, A. Cincinelli, T. Martellini, R.N. Malik, A review of PAH exposure from the combustion of biomass fuel and their less surveyed effect on the blood parameters, Environ. Sci. Pollut. Res. 22 (2015) 4076-4098.

[23] K.-H. Kim, S.A. Jahan, E. Kabir, R.J.C. Brown, A review of airborne polycyclic aromatic hydrocarbons (PAHs) and their human health effects, Environ. Int. 60 (2013) 71-80.

[24] T. Cirillo, P. Montuori, P. Mainardi, I. Russo, M. Triassi, R. Amodio-Cocchieri, Multipathway polycyclic aromatic hydrocarbon and pyrene exposure among children living in Campania (Italy), J. Environ. Sci. Health A: Tox. Hazard. Subst. Environ. Eng. 41 (2006) 2089-2107.

[25] M. Oliveira, K. Slezakova, C. Delerue-Matos, M.C. Pereira, S. Morais, Assessment of polycyclic aromatic hydrocarbons in indoor and outdoor air of preschool environments (3-5 years old children), Environ. Pollut. 208 (B) (2016) 382-394.

[26] Z. Li, A. Commodore, S. Hartinger, M. Lewin, A. Sjödin, E. Pittman, et al., Biomonitoring human exposure to household air pollution and association with self-reported health symptoms-a stove intervention study in Peru, Environ. Int 97 (2016) 195-203.

[27] Á.C. Ochoa-Martínez, T. Ruíz-Vera, L.G. Pruneda-Álvarez, A.K. González-Palomo, C.I. Almendarez-Reyna, F.J. Pérez-Vázquez, et al., Serum adipocyte-fatty acid binding protein (FABP4) levels in women from Mexico exposed to polycyclic aromatic hydrocarbons (PAHs), Environ. Sci. Pollut. Res. 24 (2017) 1962-1970.

[28] L.G. Pruneda-Alvarez, T. Ruíz-Vera, A.C. Ochoa-Martínez, F.J. Pérez-Vázquez, A.K. González Palomo, C.A. Ilizaliturri-Hernández, et al., Plasma asymmetric dimethylarginine (ADMA) levels in Mexican women exposed to polycyclic aromatic hydrocarbons (PAHs): a preliminary study, Sci. Total Environ. 572 (2016) 1195-1202. 
[29] F.J. Jongeneelen, Benchmark guideline for urinary 1-hydroxypyrene as biomarker of occupational exposure to polycyclic aromatic hydrocarbons, Ann. Occup. Hyg. 45 (2001) 3-13.

[30] A.J. Likhachev, D.Sh. Beniashvili, V.J. Bykov, P.P. Dikun, M.L. Tyndyk, I.V. Savochkina, et al., Biomarkers for individual susceptibility to carcinogenic agents: excretion and carcinogenic risk of benzo[a]pyrene metabolites, Environ. Health Perspect. 98 (1992) 211-214.

[31] C. Caux, C. O’Brien, C. Viau, Determination of firefighter exposure to polycyclic aromatic hydrocarbons and benzene during fire fighting using measurement of biological indicators, Appl. Occup. Environ. Hyg. 17 (2002) 379-386.

[32] A. Leroyer, F. Jeandel, A. Maitre, M. Howsam, D. Deplanque, M. Mazzuca, et al , 1-hydroxypyrene and 3-hydroxybenzo[a]pyrene as biomarkers of exposure to $\mathrm{PAH}$ in various environmental exposure situations, Sci. Total Environ. 408 (2010) 1166-1173.

[33] M.S. Robinson, T.R. Anthony, S.R. Littau, P. Herckes, X. Nelson, G.S. Poplin, et al., Occupational PAH exposures during prescribed pile burns, Ann. Occup. Hyg. 52 (6) (2008) 497-508.

[34] S. Fernando, L. Shaw, D. Shaw, M. Gallea, L. VanderEnden, R. House, et al., Evaluation of firefighter exposure to wood smoke during training exercises at burn houses, Environ. Sci. Technol. 50 (2016) 1536-1543.

[35] World Health Organization, Guidelines for Indoor Air Quality: Selected Pollutants, World Health Organization, Regional Office for Europe, Copenhagen, Denmark, 2010.

[36] P. Edelman, J. Osterloh, J. Pirkle, S.P. Caudill, J. Grainger, R. Jones, et al., Biomonitoring of chemical exposure among New York City firefighters responding to the World Trade Center fire and collapse, Environ. Health Perspect. 111 (2003) 1906-1911.

[37] F.D.J.R. Feunekes, F.J. Jongeneelen, H.V.D. Laan, F.H.G. Schoonhof, Uptake of polycyclic aromatic hydrocarbons among trainers in a fire-fighting training facility, Am. Ind. Hyg. Assoc. J. 58 (1997) 23-28.

[38] B.E. Moen, S. Ovrebø, Assessment of exposure to polycyclic aromatic hydrocarbons during firefighting by measurements of urinary 1-hydroxypyrene, J. Occup. Environ. Med. 39 (6) (1997) 515-519.

[39] Y. Zhou, H. Sun, J. Xie, Y. Song, Y. Liu, X. Huang, et al., Urinary polycyclic aromatic hydrocarbon metabolites and altered lung function in Wuhan, China, Am. J. Respir. Crit. Care Med. 193 (2016) 835-846.

[40] O. Alshaarawy, H.A. Elbaz, M.E. Andrew, The association of urinary polycyclic aromatic hydrocarbon biomarkers and cardiovascular disease in the US population, Environ. Int. 89-90 (2016) 174-178.

[41] B. Moorthy, C. Chu, D.J. Carlin, Polycyclic aromatic hydrocarbons: from metabolism to lung cancer, Toxicol. Sci. 145 (2015) 5-15.

[42] D.M. Gaughan, P.D. Siegel, M.D. Hughes, C.-Y. Chang, B.F. Law, C.R. Campbell, et al., Arterial stiffness oxidative stress, and smoke exposure in wildland firefighters, Am. J. Ind. Med. 57 (2014) 748-756.

[43] E.S. Soteriades, D.L. Smith, A.J. Tsismenakis, D.M. Baur, S.N. Kales, Cardiovascular disease in US firefighters-a systematic review, Cardiol. Rev. 19 (4) (2011) 202-215

[44] R.D. Daniels, T.L. Kubale, J.H. Yiin, M.M. Dahm, T.R. Hales, D. Baris, et al. Mortality and cancer incidence in a pooled cohort of US firefighters from San Francisco Chicago, and Philadelphia (1950-2009), Occup. Environ. Med. 0 (2013) 1-10.

[45] K. Golka, W. Weistenhöfer, Fire fighters combustion products, and urothelial cancer, J. Tox. Env, Health B 11 (2008) 32-44

[46] E. Pukkala, J.I. Martinsen, E. Weiderpass, K. Kjaerheim, E. Lynge, L. Tryggvadottir, et al., Cancer incidence among firefighters: 45 years of follow-up in five Nordic countries, Occup. Environ. Med. 71 (2014) 398-404.

[47] S. Youakim, Risk of cancer among firefighters: a quantitative review of selected malignancies, Arch. Environ. Occup. Health 61 (2006) 223-231.

[48] Instituto da Conservação da Natureza e das Florestas, Relatório anual de áreas ardidas e incêndios florestais em Portugal Continental-2015, Departamento de Gestão de áreas Classificadas, Públicas e de Protecção Florestal, Portugal, 2016, http://www.icnf.pt/portal/florestas/dfci/Resource/doc/rel/2015/ICNFRelatorio-Anual-Inc-2015.pdf. (Accessed 28 February 2017).

[49] World Health Organization, World Health Survey B-Individual Questionnaire. World Health Organization, Evidence and Information Policy, 2002, www.who.int/healthinfo/survey/whslongindividuala.pdf. (Accessed 15 October 2016).

[50] T. Chetiyanukornkul, A. Toriba, T. Kameda, N. Tang, K. Hayakawa, Simultaneous determination of urinary hydroxylated metabolites ofnaphthalene fluorene, phenanthrene and pyrene as multiple biomarkers ofexposure to polycyclic aromatic hydrocarbons, Anal. Bioanal. Chem. 386 (2006) 712-718

[51] A.S. Kanagasabapathy, S. Kumari, Guidelines on Standard Operating Procedures for Clinical Chemistry, World Health Organization, Regional Office for South-East Asia, New Delhi, 2000, pp. 25-28.

[52] World Health Organization, BMI Classification, World Health Organization, 2016, http://apps.who.int/bmi/index.jsp?introPage=intro 3.html. (Accessed 30 November 2016)

[53] Instituto Nacional de Estatística, Press Release, 2015, https://www.ine.pt/ xportal $/$ xmain? xpid=INE\&xpgid=ine_destaques\&DESTAQUESdest boui $=224733757 \& D E S T A O U E S m o d o=2$. (Accessed 29 November 2016)

[54] Direcção Geral de Saúde, Programa Nacional de Combate à obesidade, Direcção Geral de Saúde, 2005, http://1nj5ms2lli5hdggbe3mm7ms5. wpengine.netdna-cdn.com/files/2015/08/Programa-Nacional-de-Combate\%C3\%A0-Obesidade.pdf. (Accessed 30 November 2016).
[55] P. Booth, Electrocardiografia para técnicos de cuidados de saúde, 2nd ed., Lusodidata, Loures, Portugal, 2009.

[56] D.B. Barr, L.C. Wilder, S.P. Caudill, A.J. Gonzalez, L.L. Needham, J.L. Pirkle, Urinary creatinine concentrations in the U.S. population: implications for urinary biologic monitoring measurements, Environ. Health Perspect. 113 (2005) 192-200.

[57] World Health Organization, Biological Monitoring of Chemical Exposure in Workplace-Guidelines, World Health Organization, Geneva, 1996.

[58] T.J. Buckley, P.J. Lioy, An examination of the time course from human dietary exposure to polycyclic aromatic hydrocarbons to urinary elimination of 1-hydroxypyrene, Br. J. Ind. Med. 49 (1992) 113-124.

[59] Z. Li, L. Romanoff, S. Bartell, E.N. Pittman, D.A. Trinidad, M. McClean, et al., Excretion profiles and half-lives of ten urinary polycyclic aromatic hydrocarbon metabolites after dietary exposure, Chem. Res. Toxicol. 25 (2012) 1452-1461.

[60] S. Brzeznicki, M. Jakubowski, B. Czerski, Elimination of 1-hydroxypyrene after human volunteer exposure to polycyclic aromatic hydrocarbons, Int. Arch. Occup. Environ. Health 70 (1997) 257-260.

[61] F.J. Jongeneelen, F.E. Van Leeuwen, S. Oosterink, R.B. Anzion, L.F. van Der, R.P. Bos, et al., Ambient and biological monitoring of cokeoven workers: determinants of the internal dose of polycyclic aromatic hydrocarbons, $\mathrm{Br}$. J. Ind. Med. 47 (1990) 454-461.

[62] C. Viau, G. Carrier, A. Vyskocil, C. Dodd, Urinary excretion kinetics of 1 -hydroxypyrene in volunteers exposed to pyrene by the oral and dermal route, Sci. Total Environ. 163 (1995) 179-186.

[63] J.R. Sobus, M.D. McClean, R.F. Herrick, S. Waidyanatha, F. Onyemauwa, L.L. Kupper, et al., Investigation of PAH biomarkers in the urine of workers exposed to hot asphalt, Ann. Occup. Hyg. 53 (2009) 551-560.

[64] C. Viau, A. Vyskocil, Patterns of 1-hydroxypyrene excretion in volunteers exposed to pyrene by the dermal route, Sci. Total Environ. 163 (1995) 187-190.

[65] C. Marie, M. Bouchard, R. Heredia-Ortiz, C. Viau, A. Maitre, A toxicokinetic study to elucidate 3-hydroxybenzo(a)pyrene atypical urinary excretion profile following intravenous injection of benzo(a)pyrene in rats, J. Appl. Toxicol. 30 (2010) 402-410.

[66] C.C. Díaz-Merchán, J.R. Urrego-Novoa, N.Y. Rojas, A.I. Rodríguez-Pulido, E. Prieto-Suarez, Quantifying polycyclic aromatic hydrocarbons in urine samples taken from traffic police working in Bogota's metropolitan área, Rev. Salud. Pública 15 (2) (2013) 237-246.

[67] Y. Yamano, K. Hara, M. Ichiba, T. Hanaoka, G. Pan, T. Nakadate, Urinary 1-hydroxypyrene as a comprehensive carcinogenic biomarker of exposure to polycyclic aromatic hydrocarbons: a cross-sectional study of coke oven workers in china, Int. Arch. Occup. Environ. Health 87 (2014) 705-713.

[68] M. Wilhelm, J. Hardt, C. Schulz, J. Angerer, on behalf of the Human Biomonitoting Commission of the German Federal Environment Agency, New reference value and the background exposure for the $\mathrm{PAH}$ metabolites 1-hydroxypyrene and 1- and 2-naphthol in the urine of the general population in Germany: basis for validation of human biomonitoring data in environmental medicine, Int. J. Hyg. Environ. Health 211 (2008) 447-453.

[69] P. Apel, J. Angerer, M. Wilhelm, M. Kolossa-Gehring, New HBM values for emerging substances, inventory of reference and HBM values in force and working principles of the German Human Biomonitoring Commission, Int. J. Hyg. Environ. Health (2016), http://dx.doi.org/10.1016/j.ijheh.2016.09.007.

[70] C. Schulz, M. Wilhelm, U. Heudorf, M. Kolossa-Gehring, Update of the reference and HBM values derived by the German Human Biomonitoring Commission, Int. J. Hyg. Environ. Health 215 (1) (2011) 26-35.

[71] D.A. Haines, G. Saravanabhavan, K. Werry, C. Khoury, An overview of human biomonitoring of environmental chemicals in the Canadian Health Measures Survey: 2007-2009, Int. J. Hyg. Environ. Health (2016), http://dx.doi.org/10. 1016/j.ijheh.2016.08.002.

[72] Council recommendation on smoke-free environments. Recommendation 2009/C 296/02. Off. J. Eur. Union. C 296 (2009) 4-14.

[73] B. Marczynski, B. Pesch, M. Wilhelm, B. Rossbach, R. Preuss, J.-U. Hahn, et al., Occupational exposure to polycyclic aromatic hydrocarbons and DNA damage by industry: a nationwide study in Germany, Arch. Toxicol. 83 (2009) 947-957.

[74] H.-W. Hagedorn, G. Scherer, J. Engl, K. Riedel, F. Cheung, G. Errington, et al., Urinary excretion of phenolic polycyclic aromatic hydrocarbons (OH-PAH) in nonsmokers and in smokers of cigarettes with different ISO tar yields, J. Anal. Toxicol. 33 (2009) 301-309.

[75] P. Suwan-ampai, A. Navas-Acien, P.T. Strickland, J. Agnew, Involuntary tobacco smoke exposure and urinary levels of polycyclic aromatic hydrocarbons in the United States, 1999 to 2002, Cancer Epidemiol, Biomarkers Prev. 18 (3) (2009) 884-893.

[76] H. Lu, L. Zhu, Pollution patterns of polycyclic aromatic hydrocarbons in tobacco smoke, J. Hazard. Mater. A 139 (2007) 193-198.

[77] Portuguese Directive number 3974/2013. Diário da República, serie II. 53 (2013) 9522-9572.

[78] American Conference of Governmental Industrial Hygienists, Documentation for a recommended BEI of polycyclic aromatic hydrocarbons, in: American Conference of Governmental Industrial Hygienists, Cincinatti, Ohio, USA, 2010.

[79] H.A. Jeng, C.-H. Pan, W.-Y. Lin, M.-T. Wu, S. Taylor, G.-P. Chang-Chien, et al., Biomonitoring of polycyclic aromatic hydrocarbons from coke oven emissions and reproductive toxicity in nonsmoking workers, J. Hazard. Mater. 244-245 (2013) 436-443. 
[80] B. Rossbach, R. Preuss, S. Letzel, H. Drexler, J. Angerer, Biological monitoring of occupational exposure to polycyclic aromatic hydrocarbons (PAH) by determination of monohydroxylated metabolites of phenanthrene and pyrene in urine, Int. Arch. Occup. Environ. Health 81 (2007) 221-229.

[81] N. Gianniou, P. Katsaounou, E. Dima, C.-E. Giannakopoulou, M. Kardara, V. Saltagianni, et al., Prolonged occupational exposure leads to allergic airway sensitization and chronic airway and systemic inflammation in professional firefighters, Respir. Med. 118 (2016) 7-14.

[82] D. Miedinger, P.N. Chhajed, D. Stolz, C. Gysin, A.-B. Wanzenried, C. Schindler, et al., Respiratory symptoms, atopy and bronchial hyperreactivity in professional firefighters, Eur. Respir. J. 30 (3) (2007) 538-544.

[83] D.K. Bhalla, F. Hirata, A.K. Rishi, C.G. Gairola, Cigarette smoke, inflammation, and lung injury: a mechanistic perspective, J. Toxicol. Environ. Health B 2 (2009) 45-64.

[84] G. Cesaroni, F. Forastiere, N. Agabiti, P. Valente, P. Zuccaro, P.A. Perucci, Effect of the Italian smoking ban on population rates of acute coronary events, Circulation 117 (2008) 1121-1123.
[85] T. Raupach, K. Schafer, S. Konstantinides, S. Andreas, Second-hand smoke as an acute threat for the cardiovascular system: a change in paradigm, Eur. Heart J. 27 (2008) 386-392.

[86] J. Lewtas, Air pollution combustion emissions: characterization of causative agents and mechanisms associated with cancer, reproductive, and cardiovascular effects, Mutat. Res. 637 (2007) 95-133.

[87] O. Alshaarawy, M. Zhu, A.M. Ducatman, B. Conway, M.E. Andrew, Urinary polycyclic aromatic hydrocarbon biomarkers and diabetes mellitus, Occup. Environ. Med. 71 (2014) 437-444.

[88] H.I. Abdel-Shafy, M.S.M. Mansours, A review on polycyclic aromatic hydrocarbons: source, environmental impact, effect on human health and remediation, Egypt. J. Pet. 25 (2016) 107-123.

[89] G.K. LeMasters, A.M. Genaidy, P. Succop, J. Deddens, T. Sobeih, H. Barriera-Viruet, et al., Cancer risk among firefighters: a review and meta-analysis of 32 studies, J. Occup. Environ. Med. 48 (2006) 189-202.

[90] R.W. Hornung, L.D. Reed, Estimation of average concentration in the presence of nondetectable values, Appl. Occup. Environ. Hyg. 5 (1990) 46-51. 